\title{
HUMAN RIGHTS DISCLOSURE LITIGATION: UNCOVERING INVISIBLE MEDICAL RECORDS
}

\section{Ena Chadha*}

This article examines disclosure process and disclosure jurisprudence in human rights litigation. Based on a study of a decade of human rights disclosure rulings from across the country, this article finds that there have been increasing numbers of disclosure demands in human rights litigation and a substantial number of cases in which the disclosure pertained to personal documents and medical records of human rights claimants. While disclosure applications were adjudicated according to a relevance-confidentiality framework used ostensibly to balance privacy and procedural fairness, in reality significant personal information was disclosed based on assumptions of relevancy and under the guise of neutral labels. A closer examination of the different types of materials sought for disclosure in three employment human rights cases reveals that the medical core of certain records are rendered invisible and thereby open for access when tribunals neglect to look behind document categories and titles. The article concludes that there is heightened vulnerability on the part of persons with disabilities as targets of disclosure demands for their confidential medical information.

Cet article examine le processus de divulgation et la jurisprudence sur la divulgation dans le domaine de litiges en rapport avec les droits de la personne. Basé sur une étude d'une dizaine d'années de décisions partout au pays au sujet de la divulgation dans le domaine des droits de la personne, cet article conclut que le nombre de demandes de divulgation dans le domaine de litiges en rapport avec les droits de la personne augmente et que dans un nombre considérable de cas, la divulgation avait rapport à des documents personnels et des dossiers médicaux des réclamants de droits de la personne. Quoique on ait statué au sujet de requêtes de divulgation selon un cadre de pertinence/confidentialité utilisé de toute apparence pour maintenir un équilibre entre le respect de la vie privée et l'équité de la procédure, en réalité des renseignements personnels significatifs ont été divulgués basé sur des suppositions de pertinence et sous l'apparence d'étiquettes neutres. En regardant de plus près les diverses sortes de matériaux dont la divulgation a été demandée dans trois cas de droits de la personne dans le domaine de l'emploi, on trouve que la partie centrale médicale de certains documents ont été rendus invisibles les ouvrant ainsi à l'accès lorsque les tribunaux négligent de regarder au-delà des catégories de documents et des titres. L'auteur conclut que

* LL.B. (Saskatchewan), LL.M. (Osgoode). This article constitutes excerpts of the author's LL.M. thesis. The opinions expressed in this article are the author's alone. 
les personnes ayant des déficiences sont plus vulnérables en tant que cibles de demandes de divulgation de leurs renseignements médicaux confidentiels.

\section{INTRODUCTION}

The past twenty years has witnessed an explosion of human rights litigation in all jurisdictions across Canada. A recent annual report of the Canadian $\mathrm{Hu}-$ man Rights Tribunal indicates "...that the tone of hearings has become more adversarial and the hearing process itself fragmented by numerous motions and

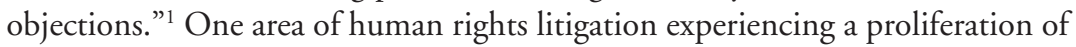
adversarial motions is the disclosure process. The burgeoning numbers of disclosure applications have included frequent demands for personal documents and confidential medical records of human rights claimants. While prior to the early 1990s disclosure was "rarely mandated" by human rights tribunals, currently disclosure is a routine matter and an increasing range of private information has "lost its privileged status."

Human rights tribunals adjudicate applications for disclosure based on the relevance-confidentiality methodology promulgated primarily out of civil sexual assault law. ${ }^{3}$ The purpose of this relevance-confidentiality test is, ostensibly, to balance a variety of important and competing interests, including the claimant's privacy rights with the respondent's right to make full answer and defence, as well as society's interest in protecting confidential communications and the proper administration of justice. This article argues that, despite the popular discourse of protecting privacy and heightened sensitivity around medical records, human rights tribunals routinely fail to recognize the existence of confidential medical records and, in so doing, obfuscate and compromise the privacy interests of claimants.

This article examines how applications for disclosure of confidential documents, particularly medical records, are treated in human rights litigation. Disclosure adjudication takes place in the context of overarching common law principles of fairness and privacy, as well as specific rules of practice. The article begins with a brief review of the concept of disclosure and the development of an expansive duty to disclose in human rights litigation. The article also considers the import of privacy and equality principles to the human rights disclosure process and the relevance-confidentiality methodology employed by tribunals to determine disclosure disputes. The article highlights the results of a survey of 181 disclosure rulings rendered by human rights tribunals across Canada for a ten and a half year period. This study found increasing disclosure demands in human rights litigation and a substantial number of cases in which the contested disclosure pertained to medical records and personal documents of claimants.

1 Canadian Human Rights Tribunal Annual Report 2005 (Ottawa: Minister of Public Works and Government Service Canada) at 3.

2 Vincent Kazmierski, "Needing Closure on Disclosure: The Application of R. v. Stinchcombe in Human Rights Proceedings” (1997) 6 Dal. J. Leg. Stud. 307 at 319.

3 The relevance-confidentiality methodology is discussed in Section 4 of this article. 
Lastly, the article analyzes three disclosure rulings which demonstrate that, while human rights tribunals uniformly express some intent to adhere to the principles of relevance-confidentiality, such best intentions are rarely borne out in reality. This article concludes that human rights tribunals have extended the concept of arguable relevance at the expense of the privacy rights of human rights claimants. Most striking, the analysis reveals significant examples of medical information buried in personal records that were initially characterized in the disclosure dispute as non-medical. The article posits that personal information is eclipsed and claimants' privacy interests are neglected when human rights tribunals fail to look behind disclosure labels and document titles which routinely mask confidential medical records.

\section{THE DUTY OF DISCLOSURE}

The general obligation to disclose relevant information in litigation or, in other words, the "duty of disclosure," is a crucial mechanism for protecting procedural fairness in legal proceedings. ${ }^{4}$ Disclosure is a key feature among the range of procedural entitlements that form an elaboration of the audi alteram partem rule. ${ }^{5}$ The audi alteram partem rule, which embodies the principles of natural justice and procedural fairness, requires that parties to a tribunal proceeding be informed of the nature of the proceeding and provided with an opportunity to be heard by the tribunal. ${ }^{6}$

Thus, disclosure is considered to be a critical component of the audi alteram partem rule because, in order for parties to meaningfully exercise their "right to be heard," parties must be given proper notice and fair opportunity to know the details of the case they have to meet. Consequently, disclosure refers to the information and documentary materials necessary to apprise the affected party of the details of the case. As the Supreme Court of Canada has observed, the purpose of disclosure is to ensure that parties have all the necessary information relevant to the matters in issue, in theory, "so that the truth may be ascertained."

While the scope of disclosure may vary depending on the nature of the administrative tribunal, the modern concept of procedural fairness mandates timely and mutual disclosure in order to eliminate unnecessary surprise in litigation. ${ }^{8}$ The quality, quantity and timeliness of information that parties garner through disclosure has been inextricably linked with whether fairness in the proceeding

4 J.M. Evans, H.N. Janisch, D. Mullan \& R.C.B. Risk, Administrative Law, 5th ed. (Toronto: Emond Montgomery, 2003).

5 A major pillar of natural justice is the principle of audi alteram partem, a Latin maxim which holds that "no person should be condemned without a hearing." See Lorne Sossin, "An Intimate Approach to Fairness, Impartiality and Reasonableness in Administrative Law" (2002) 27 Queen's L.J. 809.

6 Telecommunications Workers Union v. Canada (Radio-television and Telecommunications Commission), [1995] 2 S.C.R. 781 at para. 29.

7 M. (A.) v. Ryan, [1997] 1 S.C.R. 157 at para. 19 [Ryan].

8 Wendy Matheson and Frank Au, "Disclosure Before Administrative Hearings, Seek and You Shall Find?" Administrative Law and Practice: Beyond the Basics (Toronto: Law Society of Upper Canada, 2002) at 2. 
has been assured or impaired and, in particular, whether the respondent's capacity to make full answer and defence has been respected or thwarted.

However, until the early 1990s, it was customary that parties involved in human rights litigation only disclosed information and materials that they would rely on at the hearing. ${ }^{9}$ Prevailing human rights jurisprudence and tribunal practice made no requirement for parties to disclose documents potentially germane to the other side's case unless there was an intention to rely on that information in litigation before the tribunal. ${ }^{10}$ By the mid-1990s, this less obligatory, adversarial approach to disclosure was renounced in favour of mandatory, more co-operative and expansive disclosure. ${ }^{11}$ Disclosure law and practise underwent radical change following the Supreme Court of Canada's seminal decision in $R$. v. Stinchcombe. ${ }^{12}$ Justice Sopinka, on behalf of a unanimous Court, held that pursuant to principles of fundamental justice, the Crown, as prosecutor, was obliged by the duty of fairness to disclose all relevant evidence in its possession to the defence, notwithstanding whether the evidence was incriminatory or exculpatory. ${ }^{13}$

As a result of the 1991 Stinchcombe decision expanding the Crown's duty to disclose all evidence in its possession, courts and tribunals across the country began to recognize that, in the interests of fairness and to avoid "trial by ambush" tactics, a high standard of disclosure must exist once a hearing is convened. ${ }^{14}$ The Stinchcombe principles have been adopted into an array of administrative law proceedings, as well as precipitated broad disclosure obligations in human rights litigation. ${ }^{15}$ Leading administrative law scholars have commented that the Supreme Court's judgment in Stinchcombe revolutionized the issue of pre-hearing disclosure in administrative law matters. ${ }^{16}$ The Supreme Court again recently emphasized "the contemporary trend" favours "increased disclosure" and, observed that "mutual and reciprocal disclosure" in litigation "is the hallmark of the judicial process." ${ }^{17}$ As such, modern administrative law principles of procedural fairness recognize that the right of full answer and defence includes a right to be fully informed about the case so as to be able to properly prepare and meet the case.

Following Stinchcombe, this duty of full disclosure was quickly imposed on human rights commissions and all parties to the complaint in human rights litigation. ${ }^{18}$ With the goal of fostering fairness and facilitating the efficiency of

9 Kazmierski, supra note 2.

10 See Judith Keene, Human Rights in Ontario $2^{\text {nd }}$ ed. (Toronto: Carswell, 1992) at 294-303 for a review of the state of law regarding disclosure and motions for particulars prior to 1992.

11 OHRC v. Northwestern General Hospital, (1993) 115 D.L.R. (4th) 279 (Ont. Div. Ct.).

12 R. v. Stinchcombe [1991] 3 S.C.R. 326.

13 Ibid. at para. 29.

14 Ibid. at para. 10.

15 Kazmierski, supra note 2 at 319; Matheson \& Au, supra note 8.

16 Evans et al., supra note 4 at 352.

17 Blank v. Canada (Minister of Justice), [2006] 2 S.C.R. 319 at paras. 60 and 61.

18 One of the first cases to consider the Stinchcombe principles in the administrative law context was the human rights decision of OHRC v. Northwestern Hospital, supra note 11. See also, Potocnik v. Thunder Bay (City) (No. 1) (1995), 29 C.H.R.R. D/325 (Ont. Bd.Inq.); Dhanjal v. Air Canada, [1996] C.H.R.D. No. 4; Kearney v. Bramalea Ltd., (1998), 34 C.H.R.R. D/1 
the hearing process, common law disclosure principles and human rights rules of practice had, by the late 1990s, evolved into a compulsory obligation of full and mutual disclosure. Human rights tribunals throughout the country promulgated rules of practice that mandate a high standard of disclosure to provide any information or materials arguably relevant to the case.

In the current fora of human rights litigation, the duty of disclosure requires parties to share all arguably relevant information and documents in their possession or control relating to the complaint, notwithstanding whether the potential disclosure is favourable or adverse to their case. Several human rights jurisdictions have issued rules of practice not only stipulating this obligation of mandatory, mutual, pre-hearing disclosure, but also require parties to provide on-going disclosure during the hearing process of any arguably relevant information and documents. ${ }^{19}$ Consequently, the past decade has seen massive growth in the scope and nature of information exchanged as disclosure, as well as an escalation of disclosure demanded in human rights litigation.

There is little doubt that each of the larger human rights jurisdictions in Canada (Ontario, Federal and British Columbia) has experienced growing demands for disclosure at the litigation stage. This trend is evidenced in the ten-fold increase of disclosure rulings over the past decade. In 1995, there were five reported disclosure decisions throughout the country, growing in 2000 to 10 decisions, followed by more than twice as many in 2003 (25 cases) and again more than doubling in 2005 (54 cases). While the 2003 legislative change mandating direct access in human rights is likely, in part, responsible for the climb in disclosure litigation in British Columbia, ${ }^{20}$ there was a noticeable rise in disclosure proceedings in both the Federal and Ontario jurisdictions around 2000. ${ }^{21}$ This acceleration of disclosure litigation appears to have persisted in those jurisdictions, as well as in British Columbia.

The Canadian Human Rights Tribunal has observed that, despite the creation of procedural rules to enhance efficiency in the hearing process, there have been significantly higher numbers of pre-hearing disclosure motions. ${ }^{22}$ In its annual

(Ont. Bd. Inq.); I.M.P. Group Ltd. v. Dillman (1995), 24 C.H.R.R. D/329 (N.S.C.A.); Tannis v. Calvary Publishing Corp. (No. 1) (2000), 38 C.H.R.R. D/277 (BCHRT); Price v. Fredericton (City) (No. 2) (2004), C.H.R.R. Doc. 04-587 (N.B. Bd.Inq.).

19 See e.g. Human Rights Tribunal of Ontario, Rules of Practice (2004), Canadian Human Rights Tribunal Rules of Procedure (01-08-00), Canadian Human Rights Tribunal Rules of Procedure (03-05-04), British Columbia Human Rights Tribunal's Rules of Practice and Procedure (October 15, 2004), Alberta Human Rights and Citizenship Commission's Procedural Manual for Panel Hearings (June 2005).

20 In 2003, amendments were made to the British Columbia Human Rights Code which eliminated the British Columbia Human Rights Commission's gate-keeping and investigatory role, and consequently all contested disclosure demands now must occur before the British Columbia Tribunal.

21 In 1995, the Canadian Human Rights Tribunal had no disclosure rulings. In 2000, the Canadian Human Rights Tribunal reported four disclosure rulings, and seven rulings were reported in 2005.

22 For example, in its 2004 Annual Report, the Canadian Human Rights Tribunal noted that the workload of the Tribunal was "dramatically affected" by the "procedural wrangling" between parties: Canadian Human Rights Tribunal Annual Report 2004 (Ottawa: Minister of Public Works and Government Service Canada, 2005) at 4. See below for additional comments. The 
reports from 2000-2005, the federal Tribunal has repeatedly remarked on the increase in preliminary rulings in the area of disclosure and privilege. Noting the "deepening climate of litigiousness," ${ }^{23}$ the Federal Tribunal reported that a "noteworthy trend" in 2002 was the increase of disclosure litigation with motions seeking production of the claimant's medical records, including psychological records. ${ }^{24}$ The Federal Tribunal pointed out that "[m] otions of this kind obliged the Tribunal to reconcile privacy interests of the complainant with the respondent's right to answer the case against it." ${ }^{25}$ Again, in 2006, the Federal Tribunal reported the growing incidence of disputes regarding the adequacy of disclosure and the concomitant issue of privilege claims to protect against disclosure. ${ }^{26}$

Set out below is a discussion of the development of the privacy and equality rights principles which the Supreme Court of Canada has endorsed as crucial considerations for balancing the competing rights and interests in disclosure litigation.

\section{PRIVACY PRINCIPLES}

Contemporaneous with this expansive approach to disclosure in the administrative law setting, society at large has begun to pay greater attention to protecting the confidentiality of personal information in all public arenas. The imperative of maintaining confidentiality and promoting privacy rights in regards to personal information is apparent from the growth of literature, legislation and jurisprudence recognizing privacy as an important human rights issue. ${ }^{27}$ The right to privacy is enunciated in and protected by various international human rights instruments. ${ }^{28}$ Article 12 of the Universal Declaration of Human Rights ex-

Human Rights Tribunal of Ontario similarly commented in its 2003-2004 Annual Report on the increased volume and complexity of pre-hearing motions, see Human Rights Tribunal of Ontario Annual Report - 2003-04, at 1 (in author's possession).

23 Canadian Human Rights Tribunal Annual Report 2002 (Ottawa: Minister of Public Works and Government Service Canada, 2003) at 8.

24 This trend was accompanied by a second trend in the increase of motions seeking an order obliging the claimant to submit to an independent medical examination. See for example, Canadian Human Rights Tribunal Annual Report 2002, ibid. at 20 and in the provincial context Davis v. Toronto (City) (2005), C.H.R.R. Doc. 05-143, 2005 HRTO 7.

25 Canadian Human Rights Tribunal Annual Report 2002, supra note 23 at 8, the Tribunal notes that it has become "commonplace for the Tribunal to issue three or four rulings per case" in response to preliminary and interim motions, including disclosure. See also Canadian Human Rights Tribunal Annual Report 2003, (Ottawa: Minister of Public Works and Government Service Canada, 2004) at 37.

26 Canadian Human Rights Tribunal Annual Report 2006 (Ottawa: Minister of Public Works and Government Service Canada, 2007) at 24

27 See e.g. Richard B. Bruyer, "Privacy: A Review and Critique of the Literature" (2006) 43 Alta. L. Rev. 553; John D.R. Craig, "Invasion of Privacy and Charter Values: The Common-Law Tort Awakens" (1997) 42 McGill L.J. 355; Jeremy Debeer, "Employee Privacy: The Need For Comprehensive Protection” (2003) 66:2 Sask. L. Rev. 383; Lise Gotell, "Special Issue: Privacy Law" (2006) Alta. L. Rev. 743; Elizabeth Macfarlane, "No Lock On The Door: Privacy And Social Assistance Recipients" (1995) 1 Appeal 1.

28 See United Nations, Universal Declaration of Human Rights, adopted and proclaimed by 
plicitly states that "[n]o one shall be subjected to arbitrary or unlawful interference with his privacy, family, home or correspondence, nor to unlawful attacks on his honour and reputation." The right to privacy is at the heart of individual autonomy and dignity and is considered an essential feature of promoting other civil and social rights, such as freedom of speech and association and the right to equality.

Arguing for the creation of a "tort of invasion of privacy" in Canada, John Craig writes that there are core similarities between the justifications for protecting privacy as a fundamental value and a human right:

Privacy is a condition or state that provides the individual with a retreat from the conformist pressures of social norms... Privacy is essential to the promotion of individualism, and in particular, individual autonomy and independence...by insulating the individual from external intrusions and distractions, privacy facilitates concentration and creativity. It fosters the development of new ideas, attitudes, beliefs and lifestyles. Privacy thus breeds diversity, which is essential to any pluralist, democratic society...privacy is inherent to the notions of respect, love, friendship and trust and close human relationships are only possible if persons enjoy and accord to each other a certain measure of privacy. ${ }^{29}$

Presently in Canada, there is a significant movement towards recognizing an overarching right to privacy and protecting the confidentiality of personal information, and this is especially the case in relation to medical records. Attesting to this trend are the various statutory schemes and ethical codes that impose a duty to protect the confidentiality of personal and medical records and regulate how government institutions, commercial enterprises, custodians of health care information and other professionals handle private client information. ${ }^{30}$

Medical records are protected information pursuant to an array of Federal and provincial privacy legislation. ${ }^{31}$ Under these statutes, the right to privacy includes

General Assembly Resolution 217 A (III), December 10, 1948. A similar privacy guarantee is pronounced in Article 17 of the International Covenant on Civil and Political Rights, to which Canada acceded in 1976. United Nations, International Covenant on Civil and Political Rights, adopted by General Assembly Resolution 2200A (XXI), December 16, 1966. Recently, the United Nations General Assembly adopted the Convention on the Rights of Persons with Disabilities, which includes an article broadly mandating respect for the privacy, including the confidentiality of personal, health and rehabilitation information of persons with disabilities: Convention on the Rights of Persons with Disabilities, Adopted by UN GA 13 December 2006: UN GAOR Plen., 61st Sess., $76^{\text {th }}$ Mtg., UN Doc. GA/10554 (2006), open for Signature March 2007.

29 Craig, supra note 27 at 358.

30 For example Ontario Mental Health Act, R.S.O. 1990, c.M.7, Public Hospital Act, R.S.O. 1990, c. P.40, Nursing Act, S.O. 1991 c.32, Canadian Medical Association Ethical Code etc.

31 See e.g. in Ontario the Personal Health Information Protection Act, 2004, S.O. 2004, c.3 and federal legislation includes Personal Information Protection and Electronic Documents Act, S.C. 2000, c. 5. Examples from other provinces include: in Alberta the Health Information Act, 
the right to determine with whom to share and disclose health information and to exercise control over use and access of such information. The Federal Personal Information Protection and Electronic Documents Act declares that its purpose is to establish "rules to govern the collection, use and disclosure of personal information in a manner that recognizes the right of privacy of individuals with respect to their personal information" given this "era in which technology increasingly facilitates the circulation and exchange of information." ${ }^{32}$

The trend towards safeguarding personal information has also materialized in criminal and civil proceedings, particularly sexual assault litigation. ${ }^{33}$ The special protection that personal, medical and therapeutic records deserve has been extensively explored in several landmark Supreme Court of Canada judgments: R. v. Osolin, R. v. O 'Connor, A. (M.) v. Ryan and R. v. Mills. ${ }^{34}$ Each of these cases dealt with the demands of one party (accused/defendant) to access the confidential records of another party (victim/complainant). In this line of cases, the Supreme Court interpreted the constitutional protections of life, liberty and security of the person, as well as the protection against unreasonable search and seizure, to include the right to privacy. The Supreme Court recognized that the disclosure of confidential records jeopardizes physical and emotional integrity by interfering in the relationship between the individual and their physician or counselor and undermines societal interests in promoting physical and psychological health. ${ }^{35}$

The Supreme Court also strenuously endorsed the notion that the section 15 right to equality under the Canadian Charter of Rights and Freedoms held by victims of sexual assault offences must also protect and promote respect for their privacy interests:

The intimate nature of sexual assault heightens the privacy concerns of the victim and may increase, if automatic disclosure is the rule, the difficulty of obtaining redress for the

R.S.A. 2000, c.H-5; in British Columbia the Personal Information Protection Act, S.B.C. 2003 c. 63; in Saskatchewan The Health Information Act, S.S. 1999 c.H-0.021; in Manitoba the Personal Health Information Act, C.C.S.M. c. P33.5; in New Brunswick the Protection of Personal Information Act, S.N.B. 1998, c. P-19.1.

32 Personal Information Protection and Electronic Documents Act, ibid. at section 3.

33 See e.g. the caselaw analysis in Jamie Cameron, "Victim Privacy and the Open Court Principle" (Ottawa: Department of Justice, 2004); for overview of the development of Bill C-46, Lise Gotell, "The Ideal Victim, the Hysterical Complainant, and the Disclosure of Confidential Records: The Implications of the Charter for Sexual Assault Law" (2002) 40 Osgoode Hall L.J. 251, and Karen Busby, "Third Party Records Cases Since R. v. O'Connor" (2000) 27 Man. L.J. 355.

34 R. v. Osolin, [1993] 4 S.C.R. 595; R. v. O'Connor, [1995] 4 S.C.R. 411; Ryan, supra note 7; R. v. Mills, [1999] 3 S.C.R. 668.

35 In Ryan, supra note 7, the Supreme Court emphasized the necessity to ensure that the common law of privilege evolves to reflect Charter values of privacy and equality. Justice McLachlin, for the majority, explained that: "One such value is the interest affirmed by s. 8 of the Charter of each person in privacy. Another is the right of every person embodied in s. 15 of the Charter to equal treatment and benefit of the law. A rule of privilege which fails to protect confidential doctor/patient communications in the context of an action arising out of sexual assault perpetuates the disadvantage felt by victims of sexual assault, often women." 
wrong. The victim of a sexual assault is thus placed in a disadvantaged position as compared with the victim of a different wrong. The result may be that the victim of sexual assault does not obtain the equal benefit of the law to which s. 15 of the Charter entitles her. She is doubly victimized, initially by the sexual assault and later by the price she must pay to claim redress -- redress which in some cases may be part of her program of therapy. These are factors which may properly be considered in determining the interests served by an order for protection from disclosure of confidential patient-psychiatrist communications in sexual assault cases. ${ }^{36}$

The Court further noted that demands for disclosure are often founded upon irrelevant generalizations or prejudicial stereotypes about women and people with disabilities, in particular that victims of sexual offences and people with mental disabilities are wrongly assumed to have problems with reliability and credibility. The Supreme Court emphasized that judges must demonstrate an "acute sensitivity" to whether such negative myths and stereotypes underpin speculative requests for production. ${ }^{37}$ The Court cautioned that in order for personal information, such as therapeutic records, to be relevant, there must be a legitimate purpose asserted for the potential disclosure, i.e., that it is not a speculative, obstructive or unmeritorious request for disclosure. ${ }^{38}$ The Supreme Court's jurisprudence commands that disclosure analysis integrate privacy and equality principles and important threshold assessment of relevance be informed by an understanding of the privacy and equality rights at issue in the case. ${ }^{39} \mathrm{By}$ acknowledging that the common law rules of evidence must evolve to "reflect the social and legal realities of our time" and by promoting a heightened sensitivity to equality issues, the Supreme Court has profoundly changed the legal landscape with respect to disclosure of confidential information. ${ }^{40}$

Against this backdrop, one would expect that human rights tribunals would also evince heightened sensitivity to privacy concerns in disclosure litigation. However, as discussed later, this article found that tribunals not only grant extensive disclosure, including access to confidential information, but often medical records are released without scrutiny because such documents bear neutral labels and titles. The next section outlines the three-step analytical framework

36 Justice McLachlin, for the majority in Ryan, supra note 7 at para. 30.

37 R. v. Mills, [1999] 3 S.C.R. 668 at para 93.

38 In R. v. Mills, ibid. the Court stated "the right to make full answer and defence must be determined in light of privacy and equality rights of complainants and witnesses. It is clear that the right to full answer and defence is not engaged where the accused seeks information that will only serve to distort the truth-seeking purpose of a trial, and in such a situation, privacy and equality rights are paramount", at para. 94. See also R. v. O'Connor, supra note 34 at para. 22.

39 In $R . v$. O'Connor, supra note 34 at para. 31, the majority of the Supreme Court of Canada indicated that "potential prejudice to the complainant's dignity, privacy or security of the person that would be occasioned by production of the record in question" is an important factor for consideration in "balancing the parties competing interests" in the disclosure demands.

40 Busby, supra note 33. 
employed by human rights tribunals to adjudicate disclosure applications. It describes the principal considerations in assessing "arguable relevance," the test for "case by case" privilege and safeguards for protecting privacy. The article concludes that there was inconsistent application of this relevance-confidentiality methodology by the tribunals.

\section{RELEVANCE AND CONFIDENTIALITY METHODOLOGY}

Most human rights tribunals employ a three-step analytical framework focusing on the common law principles of relevance-confidentiality to adjudicate disclosure demands. The first step in this framework requires the party seeking disclosure to establish that the sought after information or documents are "arguably relevant" to a matter or issue in the complaint.

\section{A. Is the Demanded Disclosure Arguably Relevant?}

Although "arguable relevance" appears to be widely accepted as the appropriate measure for screening disclosure demands, there is no comprehensive definition of this concept. As one commentator states, "[r]elevance is not a term which lends itself to precise and clear definition." 41 The authoritative evidentiary treatise, The Law of Evidence in Canada, indicates that "the first step in determining what is relevant is to identify the facts that are in issue in the case." ${ }^{42}$

Author W.N. Renke explains that the "term relevance refers to a particular relation between facts: one fact is relevant to another when the first fact tends to prove or disprove the existence of the other." ${ }^{33}$ The capacity to prove or disprove something is often referred to as the degree to which the disclosure is "logically probative" to a fact or issue in the case. The onus rests on the party seeking disclosure of the information to establish that the material is logically probative, i.e., that there is an inferential link between the sought after information and the fact in dispute. ${ }^{44}$ Thus, in order to satisfy the first step of the relevance-confidentiality framework, the party seeking disclosure must, at minimum, demonstrate that the requested disclosure contains information which "tends to prove or disprove the existence" of a matter in the human rights complaint.

As previously noted, through the line of sexual assault records cases, the Supreme Court has provided greater depth to disclosure adjudication by injecting human rights values of dignity, security and equality into the concept of "arguable relevance" and mandated these factors be considered in balancing the parties competing interests in the disclosure demands. The Supreme Court recognized that, as part of the right to equality, there is fundamental entitlement to privacy and an individual's control over their personal medical information is

41 Loretta N. Colton, “R. v. Stinchcombe: Defining Disclosure” (1995) 40 McGill L.J. 525.

42 John Sopinka, Sidney N. Lederman \& Alan W. Bryant, The Law of Evidence in Canada, 2nd ed. (Toronto: Butterworths Canada, 1999) at paras. $2.36 \& 2.38$.

43 W. N. Renke, "Controlling the Disclosure of Witnesses' Medical Records" (1994) 3 Health Law Review 31, citing Sopinka et al ibid. at 22 and Sir Rupert Cross and C. Tapper, Cross on Evidence, 7th ed. (London: Butterworths, 1990) at 51.

44 Marilyn MacCrimmon, “Trial by Ordeal” (1996) 1 Can.Crim.L.Rev. 31 citing R. v. O'Connor, supra note 33 at para. 22. 
necessary to protect their dignity and integrity. The principles articulated by the Supreme Court require decision makers to carefully examine disclosure applications to ensure that the request does not rely on or invoke prejudicial stereotypes to rationalize "arguable relevance." The Court recognized that fallacious and demeaning stereotypes have been routinely cited in sexual offences cases when seeking disclosure of the victim's health records. The myths and stereotypes include the misguided belief that women make false sexual assault allegations, and or, the testimony of a person with a mental disability is not trustworthy. As such, in evaluating a respondent's assertion of "arguable relevance," tribunals must be sensitive to equality concerns and attuned to ensure that the disclosure claim is neither founded upon negative stereotypes, nor exacerbates, pre-existing equality-related disadvantage. ${ }^{45}$

After establishing an "arguable relevance" nexus between the sought after information and the facts or issues in the complaint, the second step of the relevance-confidentiality framework requires a consideration of the competing interests in the information. This entails an evaluation of whether to grant or refuse disclosure is more prejudicial. However, if the information sought does not pass the initial "arguable relevance" threshold, then it is unnecessary for the Tribunal to deal with this second stage of the analysis and, as such, the request for disclosure should be dismissed. ${ }^{46}$

\section{B. Are there Competing Interests in the Requested Disclosure?}

The second step involves balancing the competing interests in the sought after disclosure. This is usually a comparison of the probative value of the information to the importance of procedural fairness versus the prejudice of disclosure that attaches to the contested materials. Author John Dawson has dubbed this assessment the "disclosure calculus." ${ }^{77}$ The "disclosure calculus" is the requirement that the interests of one party to maintain confidentiality be evaluated against the interests of the other party to be fairly apprised of the case. Most often, it is the weighing of the claimant's right to privacy against the respondent's right to make full answer and defence.

If the demanded disclosure implicates private information or confidential relationships, then the analysis of the party's privacy interests triggers a consideration of whether the information is shielded by privilege.$^{48}$ For situations where traditional privilege (e.g., solicitor-client) cannot be invoked, the Supreme Court of Canada has adopted the following four prong "Wigmore Test" for determining whether "case-by-case privilege" applies:

(i) The communications at issue originate in confidence with the expectation that they will not be disclosed,

45 Supra notes 34-39.

46 For example, Biederman v. Banfai (2000), 38 C.H.R.R. D/395 (Ont. Bd. Inq.) at para. 16.

47 John Dawson, "Compelled Production of Medical Records" (1998) 43 McGill L.J. 25 at 29.

48 The four most common grounds of privilege are: solicitor-client privilege, settlement privilege, public immunity privilege and spousal privilege. However, in addition to these classes of privilege, there is also "case-by-case" privilege, referring to the fact confidentiality can be determined to exist because it is critical to the relationship. 
(ii) The element of confidentiality must be essential to the full and satisfactory maintenance of the relationship between the parties to the communication,

(iii) The relationship is one which in the opinion of the community ought to be "sedulously fostered," and

(iv) The interests served by protecting the communications from disclosure outweigh the interests of pursing the truth and disposing correctly of the litigation. ${ }^{49}$

Dawson explains "confidential communications within special relationships may be considered privileged on a case-by-case basis" and the "Wigmore criteria constitute the general framework in Canada for the common law privilege analysis in respect of confidential material." ${ }^{50}$ Examples of special relationships generating confidential communications and information which commonly invoke case-by-case privilege are counselor-client, priest-penitent and doctor-patient. Unlike the classic categories of privilege, e.g., solicitor-client and settlement privilege, there is no presumption of automatic preservation of confidentiality in case-by-case privilege. Rather, the onus rests on the party seeking to guard the privacy of the information to demonstrate the relationship, communications and information should, on public policy grounds, be shielded from disclosure.

Based on the caselaw survey, this article found that tribunals generally concluded the privacy concerns, as set out in the first three prongs, were engaged when the contested disclosure was medical records. For the tribunals that undertook this analysis, often their decisions turned on the fourth branch of the "Wigmore Test." This left the tribunal to decide whether the interests served by protecting the information from disclosure outweighed the interests of pursuing the truth and disposing correctly of the litigation. Unfortunately, as discussed later, few tribunals carried out a full confidentiality analysis and, even in those situations where all four "Wigmore" criteria were considered, the evaluation of the claimant's right to privacy was fleeting and under-developed.

In sum, the second step of the analysis requires the tribunal to determine whether the benefits of procedural fairness from an order of disclosure outweigh the negative consequences of infringing the right to privacy. If the tribunal determines that the party's full answer and defense will be unreasonably impaired and the administration of justice necessitates some disclosure, then the tribunal must next consider the type and degree of disclosure.

\section{Should Safeguards Apply to the Demanded Disclosure?}

If the "case by case privilege" criteria are not satisfied and the tribunal concludes that the importance of pursuing the truth and correctly disposing of the litigation warrants disclosure, then the tribunal must undertake the additional, important step of determining the appropriate scope of disclosure and to what extent any safeguards should be applied to lessen the intrusion on privacy. In Pritchard v. Ontario (Human Rights Commission), the Supreme Court of Canada

49 Ryan, supra note 7 at 170, para. 20. See also R. v. Gruenke [1991] 3 S.C.R. 263.

50 Dawson, supra note 47 at 58. 
dealt with a human rights commission's claim of privilege over a legal opinion. The Court observed that "privilege and procedural fairness may co-exist without being at the expense of each other." 51 It would appear that limited disclosure, i.e., restricting access to or redacting parts of the information, may be one means of achieving this co-existence.

In M.(A.) v. Ryan, Justice McLachlin described this type of limited disclosure as "partial privilege." 52 In that civil sexual assault case, the Supreme Court concluded that the risk of possible injustice to the defendant and potential harm of disclosure to the claimant could be minimized by an examination of contested disclosure by the judge. McLachlin J., writing for the majority, expressly rejected an "all or nothing" approach to privilege. ${ }^{53}$ By inspecting the documents, the decision maker may ascertain what information or materials should be extracted as irrelevant or unduly prejudicial. McLachlin J stated:

... I would venture to say that an order for partial privilege will more often be appropriate in civil cases where, as here, the privacy interest is compelling. Disclosure of a limited number of documents, editing by the court to remove nonessential material, and the imposition of conditions on who may see and copy the documents are techniques which may be used to ensure the highest degree of confidentiality and the least damage to the protected relationship, while guarding against the injustice of cloaking the truth. ${ }^{54}$

Thus, in the human rights context, if the tribunal decides that partial privilege may be appropriate, the tribunal should consider vetting the documents to redact irrelevant or prejudicial information and/or attach certain terms and conditions to limit the disclosure ordered, such as restricting the temporal scope or range of the disclosure or nature or type of the materials. This caselaw survey found that tribunals were more inclined to grant disclosure subject to confidentiality conditions, such as restrictions on the number of copies that could be made, who was permitted to have access to the disclosure (e.g. only counsel and experts), restricting the use of the documents that were ordered for production, and redacting identifying information. ${ }^{55}$ Less often tribunals ordered initial dis-

51 Pritchard v. Ontario (Human Rights Commission), [2004] 1 S.C.R. 809 at para. 31.

52 Ryan, supra note 7 at para. 35.

53 Ibid. at para. 34.

54 Ibid. at para. 33.

55 For example, in Marc v. Fletcher Challenge Canada Ltd. (No. 4) (1999), 35 C.H.R.R. D/115 (B.C.H.R.T.), the Claimant sought the employment personnel records of a Respondent witness. The Tribunal recognized that the contested personnel file would likely include confidential personal information (e.g. addresses, phone numbers, references to family members, physician's reports, etc.), which would need to be deleted prior to disclosure. Other examples of rulings with different types of partial disclosure and confidentiality conditions see, Day v. Canada (Dept. of National Defence)(No. 1), (2002), C.H.R.R. Doc. 03-024 (C.H.R.T.); Abouchar v. Toronto (Metro) School Board (No. 2) (1996), CHRR Doc. 96-205 (Ont. Bd. Inq.); Biederman v. Banfai, supra note 44; Davis v. Toronto (City) (2005), C.H.R.R Doc. 05-143, 2005 HRTO 7; Pleasant v. Mainline Manufacturing \& Installing Inc. (September 9, 2005)(HRTO); McConnell 
closure to either the tribunal itself or the claimant for inspection and vetting of irrelevant or privileged materials. ${ }^{56}$

\section{Summary of Relevance-Confidentiality Methodology}

The relevance-confidentiality methodology mandates that decision makers undertake three specific lines of inquiry to ensure a thorough and balanced disclosure analysis: firstly, a threshold assessment of "arguable relevance;" secondly, a weighing of competing interests; and lastly, a consideration of confidentiality conditions. Cleary, all three stages of the analysis are equally valuable and necessary for upholding procedural fairness and protecting privacy. As John Dawson contends, the criteria of relevance, the balancing of interests and the production screening "are the necessary means of separating legitimate requests from fishing expeditions and conjecture." 57

In summary, the three-step relevance-confidentiality framework for determining disclosure is as follows:

i.) The tribunal should determine whether the sought after information is arguably relevant. The party seeking disclosure of the information or documents must demonstrate a nexus between the disclosure sought and the issues in dispute. The requested disclosure must be probative and arguably relevant to an issue in the case and the claim of arguable relevance must not be founded upon negative stereotypical notions. This is meant to prevent disclosure for speculative or unmeritorious purposes. If there is no arguable relevancy, then the disclosure request should be denied;

ii.) The tribunal must next balance the parties' interests in the disclosure and any prejudice that may inure from restricting or providing disclosure. If there are confidentiality concerns, the tribunal should undertake a caseby-case privilege analysis, giving careful consideration to issues of privacy and equality, as well as the right to full answer and defence; and

iii.) If the tribunal determines that full or partial disclosure is necessary, then safeguards to protect privacy

v. Yukon Territory Govt. (Public Service Commission)(April 23, 1998)(Yukon), Desai v. The Owners, Strata Plan VR 123 (2005), C.H.R.R. Doc. 05-187, 2005 BCHRT 149, Gaucher v. Canada (Armed Forces) (No. 2) (2005), C.H.R.R. Doc. 05-767, 2005 CHRT 42; Anonuevo. General Motors et al. (No. 2) (1997), CHRR Doc. 97-204 (Ont. Bd. Inq.); Brampton Children's Residential Services v. Sandringham Place (February 1, 2002) (Ont. Bd. Inq.); Moffatt v. Kinark Child and Family Services et al. (April 21, 1997) (Ont. Bd. Inq.); Snowling v. St. Catharines (City) (No. 2) (1995), 24 C.H.R.R. D/195 (Ont. Bd. Inq.).

56 See R. v. O'Connor, supra note 34, for the background to this inspection approach.

57 Dawson, supra note 47 at 54 and 58 
and minimize prejudice should be considered, such as inspecting the documents in order to redact passages, removing documents that raise concerns, or limiting circulation of the materials.

In conclusion, the intent of this methodology is to establish a sufficient level of protection for both procedural fairness and privacy. Unfortunately, as discussed below, we see that tribunals often undertake a mechanical recitation of the principles underpinning this analysis and fail to integrate serious consideration of the privacy and equality rights principles articulated by the Supreme Court of Canada.

\section{RESULTS OF CASELAW SURVEY}

A broad survey of all human rights decisions rendered by Federal and provincial human rights tribunals between January 1995 to July 2006 located 181 disclosure rulings. ${ }^{58}$ The primary method used for compiling the cases was research through two main legal database search engines: the Canadian Human Rights Reporter (CHRR) and QuickLaw (QL), as well as tribunal websites. ${ }^{59}$ Out of the total 181 disclosure rulings collected from January 1995 to July 2006, slightly over one half of the cases emanated from British Columbia. ${ }^{60} \mathrm{~A}$ broad range of documents were the subject of the disclosure applications, including:

- medical records

- business records (e.g., financial statements, human resources policies, business plans, customer surveys)

- employment documents (e.g., personnel files, workers compensation files)

- personal documents (e.g., letters, journals, diaries, notes, academic records)

58 This study did not include disclosure rulings from the Quebec Commission des Droits de la Personne et des Droits de la Jeunesse because, all but one Court of Appeal decision, were available in French language only. The 1995 commencement date was selected as the approximate point in time when the Ontario Human Rights Board of Inquiry introduced its first set of rules of practice for human rights hearings which established a framework for exchange of disclosure between parties. Although there were numerous judicial reviews dealing with a party's disclosure demands during the commission process, such as seeking investigation files and legal opinions, these decisions were not included in the compiled results because they did not involve the litigation of the merits of a human rights complaint before a tribunal.

59 The QL and CHRR results were then cross-referenced with and supplemented by researching the commission and tribunal publicly available internet websites for any other disclosurerelated human rights rulings which may not have been collected and "published" by the private databases. Several unreported rulings were discovered this way. Also, the CHRR reported the existence of three early disclosure decisions which were not available electronically and consequently, paper copies of these rulings were obtained through requests to the tribunal's registrar's office.

60 The study excluded "technical" compliance rulings, wherein a tribunal simply ordered one or more of the parties to fulfill their obligation to file pleadings and provide disclosure in compliance with a set deadline without examination of a specific disclosure demand. 
- government documents (e.g., Cabinet memoranda, policy statements)

- police files

- human rights commission files (e.g., investigation notes, legal opinions)

- criminal record checks

- income records (e.g., income tax records, bank statements)

- settlement and legal documents

\section{A. Key Findings}

\section{Characteristics of the Moving Party}

Respondents made the majority of the demands for disclosure. Respondents were the moving party in $90 \%$ of the cases seeking medical disclosure and 59\% of all disclosure applications. Claimants were the moving party in approximately one third of all disclosure motions and, in those instances, claimants routinely sought business documents and employment records. ${ }^{61}$ There were rare occasions when a human rights commission or a claimant sought access to medical information and, in such situations, the medical disclosure typically related to the claimant's own medical records in the possession of a respondent employer or third party. Out of all the 181 cases surveyed for the ten and a half year period, there was only one case in which a claimant sought medical disclosure about a respondent. ${ }^{62}$

\section{Gender and Disability Leading Grounds in Disclosure Applications}

Gender and disability dominated as the grounds most cited in disclosure applications. Over $40 \%$ of disclosure applications were gender-related complaints (sex discrimination and sexual harassment). Although it may be of little surprise that disability was a common feature in medical disclosure litigation, disability was also the leading ground present in general disclosure applications for the provincial jurisdictions and the second most frequently cited ground for the Federal jurisdiction. ${ }^{63}$ While there was greater representation of physical disability in the general disclosure applications, mental disability was slightly more pronounced in medical disclosure applications.

\section{Gender Representation in Disclosure Applications}

The gender breakdown between the category of general versus medical disclosure was almost identical. The number of male claimants in general disclosure applications $(41 \%)$ was relatively equal to the number of male claimants in med-

61 Given that the majority of human rights complaints in all jurisdictions arise out of the employment sector, it is no surprise that the preponderance of disclosure applications arose from complaints in the area of employment. This was followed by complaints in the area of services. $80 \%$ of the disclosure sought by Claimants involved business and employment records.

62 Watt v. Foster (2001), 40 C.H.R.R. D/106 (BCHRT).

63 Gender-related grounds were cited in the majority of Federal disclosure applications. 
ical disclosure applications (43\%). Women constituted $48 \%$ of both general and medical disclosure applications. Thus, consistently, there was a slightly higher representation of female claimants in both general and medical disclosure applications.

\section{Broad Range of Disclosure Sought}

Not only did respondents predominate as the party most often pursuing disclosure, the survey revealed that respondents sought disclosure of a diverse range of claimant information, including items like: personal notes, correspondence and diaries ${ }^{64}$ income records, ${ }^{65}$ education records ${ }^{66}$ and personnel records. ${ }^{67}$ As such, respondents' disclosure demands reached for a wide spectrum of documents regarding claimants' personal, medical and financial lives. When tallied together, almost $65 \%$ of all the disclosure sought by respondents involved medical and personal information.

\section{Rationales for Seeking Disclosure}

Respondents put forward four principal "arguable relevance" justifications for seeking general disclosure: the demanded disclosure was arguably relevant to liability, remedies, systemic issues and credibility.

\section{Types of Tribunal Rulings}

Seventy-six per cent $(76 \%)$ of general disclosure applications resulted in either full or partial disclosure. Tribunals were equally likely to order partial disclosure and full disclosure and less likely to outright deny disclosure applications. Although less than $25 \%$ of general disclosure applications were refused, tribunals most often denied disclosure if the respondent's demands were too broad or if the respondent already had some information in its possession.

\section{Significant Medical Disclosure Granted}

In total, $81 \%$ of all medical disclosure applications granted some degree of disclosure.

64 See e.g. Curling v. Torimiro (1999), C.H.R.R. Doc. 99-203 (Ont. Bd. Inq.); Guay v. RCMP (2004), C.H.R.R. Doc. 04-650, 2004 CHRT 34; C. v. A. (2002), 43 C.H.R.R. D/395 (BCHRT); Cucek v. British Columbia (Ministry of Children and Family Development) (No. 1) (2003), 47 C.H.R.R. D/245 (BCHRT).

65 See for example, Green v. Public Service Commission et al. (July 3, 2003) 2003 CHRT 25 (CHRT); Tubbs v. Universal Workers Union (No. 1) (2005), C.H.R.R. Doc. 05-267, 2005 HRTO 16; Bushey v. Sharma (No. 1) (2003), C.H.R.R. Doc. 03-049, 2003 CHRT 5; Ali v. Allard and Co. (2003), C.H.R.R. Doc. 03-036, 2003 BCHRT 5; Becker v. Cariboo Chevrolet Pontiac Buick GMC Ltd (No. 4) (2005), C.H.R.R. Doc. 05-370, 2005 BCHRT 281.

66 See e.g. Louis v. Tostenson Pharmacy et al., (2004), C.H.R.R. Doc. 04-411, 2004 BCHRT 264; Gichuru v. Law Society of British Columbia (No. 3) (2006), C.H.R.R. Doc. 06-542, 2006 BCHRT 402; Brady v. Interior Health Authority (No. 1) (2005), C.H.R.R. Doc. 05-246, 2005 BCHRT 200.

67 See e.g., Bains v. Metro College Inc. (No. 1) (2003), C.H.R.R. Doc. 03-235, 2003BCHRT 66; McAvinn v. Strait Crossing Bridge Ltd. (No. 3) (2001), C.H.R.R. Doc. 01-068 (C.H.R.T.); Ali v. Allard and Co. (2003), C.H.R.R. Doc. 03-036, 2003 BCHRT 5. 


\section{Confidential Records Targeted in Gender Disclosure Applications}

As previously noted, over $40 \%$ of disclosure applications were gender-related complaints (sex discrimination and sexual harassment). Over one-third of these gender-related disclosure cases involved demands for medical records. When tallied with the number of instances where personal documents were also being pursued, well over half of the disclosure demands in gender-related cases sought access to the female claimants' confidential medical and personal information.

\section{B. Conclusion}

In conclusion, the data reveals that, regardless of the nature of the information sought, female claimants and claimants with disabilities are predominately the targets of the disclosure demands. The caselaw survey indicates that there is little difference in the "arguable relevance" rationales put forward by the respondents in seeking general or medical disclosure.

And finally, although it may seem counterintuitive to ethical and legal values that accord enhanced confidentiality protection for medical records, the abovenoted data clearly indicates that more medical disclosure applications were granted $(81 \%)$ compared to general disclosure applications $(76 \%)$. In fact, despite the rhetoric of protecting privacy of medical records because of the highly personal content and the purported stringency of the relevance-confidentiality analysis, medical information was readily accessible to disclosure. The picture that emerges is when a disclosure application includes a request for medical information, it is as likely (if not slightly more likely) to be granted as any other general disclosure application. The next section of this article explores how neutral titles obscure the confidential content of information and how reliance on such neutral labels led some tribunals to unwittingly permit access to potentially very personal information.

\section{INVISIBLE MEDICAL RECORDS}

Upon closer examination of the different types of disclosure documents being sought and how requests for "non-medical" information were assessed, it became evident that there was little consistent application of the relevance-confidentiality methodology by the tribunals. Some tribunals diligently evaluated the individual disclosure documents in tandem with the relevance-confidentiality principles. Some tribunals gave only cursory consideration of how the principles applied to the particular materials that were the subject of the disclosure demands. And other tribunals simply recited the principles without any direct contemplation of the precise information or documents being pursued. Despite numerous tribunal decisions which devoted considerable space to enumerating the relevance-confidentiality framework as the proper test for assessing disclosure applications, a deeper analysis of the specific disclosure demands and the tribunals' reasons revealed serious, hidden problems.

A careful review of the exact nature of the information and the individual documents sought by respondents exposed several instances of disclosure requests involving unidentified or, in other words, "invisible" medical information. Without actually delving into the physical files and reading the documents, it is 
obviously impossible to quantify how much medical disclosure was concealed. However, as is discussed below, the descriptions of the contested disclosure provided a telling glimpse into the materials, upon which there is convincing basis to conclude that confidential medical information is being inadvertently disclosed by human rights tribunals under the premise of non-medical information.

\section{A. Examples of Invisible Medical Records Disclosure}

The caselaw survey uncovered numerous situations where, based on the details canvassed in the tribunal's decision, it was evident that the documents sought implicated medical records and, therefore, although unidentified, confidential medical information was at risk of disclosure. The medical records were hidden or, in other words rendered "invisible," as a result of being buried amongst other non-medical documents and information.

Based on a review of these cases, three which are discussed below, it appears that, when respondents' disclosure requests were reduced to mere categories of records and labels, the personal nature of the information was neutralized. As such, the relevance-confidentiality test was side-stepped and the confidential core of the records evaded scrutiny. Consequently, it is likely that a considerably higher amount of medical information was actually accessed by respondents than indicated by the data in section 5 of this article.

Set out below are three cases from British Columbia, where, as previously noted, the majority of the disclosure rulings were issued. ${ }^{68}$ These three decisions were selected as examples of the "invisible records" phenomenon because the respondents' requests for disclosure in these cases represented a diverse range of seemingly non-medical information: immigration records, education records and government records. These cases also reflected the frequency by which respondents, in all jurisdictions across the country, relied upon the rationale that the disclosure sought was arguably relevant because it contained employmentrelated information.

An analysis of these three sample rulings reveals a variety of hidden medical information that went undetected by the human rights tribunals. The examination indicates that tribunals failed to uncover the medical information because the disclosure requests were not subjected to the relevance-confidentiality analysis necessary for screening confidential records. The cases reviewed in this section indicate that claimants' privacy rights in their personal medical information are not only ignored, but sometimes undermined, when tribunals fail to evaluate the disclosure request through the relevance-confidentiality criteria because records wear the mask of arguably relevant employment-related materials.

68 Out of the 181 disclosure decisions collected from across the country, 97 decisions were from British Columbia. While all three cases studied in this section are from the same jurisdiction, as discussed later in the article, these cases are representative of similar rulings from other jurisdictions. 


\section{Milay v. Atbwal ${ }^{99}$}

In Milay v. Athwal, the Respondent employer sought access to the Claimant's entire immigration file. The Claimant was employed by the Respondent as a "live-in caregiver" pursuant to a special immigration program. The Claimant alleged that she quit her job because of sexual harassment. The Respondent demanded disclosure of all the Claimant's immigration documents, including all correspondence and applications, for the purposes of examining what information the Claimant supplied to immigration authorities to obtain and possibly vary her work permit visa.

The Claimant asserted that this degree of disclosure "expose[d] her to a needless invasion of privacy." 70 Given the Respondent's objective in seeking the immigration records was to ascertain whether and, on what basis, the Claimant's work permit status changed, the Tribunal concluded that the Respondent did not require access to the entire immigration file. The Tribunal found that only those documents related to the Claimant obtaining her immigration work permit both during and after her employment with the Respondent were potentially relevant. The Tribunal ordered disclosure of the Claimant's employment-related immigration documentation and any information and applications provided to vary the terms of her work permit.

The Tribunal in Milay failed to articulate, even in the most perfunctory manner as most other Tribunals had, the relevance-confidentiality principles. The Tribunal did not investigate any potential confidentiality issues. Although the Tribunal noted that the Claimant had expressed "privacy concerns," the Tribunal bluntly dismissed this matter in a single sentence on the basis that the Claimant had not particularized her concerns. The Tribunal's hasty approach to the issue of privacy suggests that the Tribunal was easily convinced by the label of "employment documents" and the seeming relevance of the work permit.

While the Tribunal was properly concerned that the Claimant's entire immigration file was not relevant to the sexual harassment complaint, it is unclear whether the Tribunal was alert to the fact that the disclosure it had granted could include medical records. Generally, all persons seeking entry to Canada as an immigrant or worker must satisfy certain medical admissibility criteria and undergo a medical examination. As such, employment-related immigration records will, at the very least, comprise of a detailed medical examination report, including results from a urinalysis test, blood screening (e.g., syphilis serology) and chest $\mathrm{x}$-ray, etc. ${ }^{71}$

Moreover, an application to vary a work permit (which was the one rationale put forth by the Respondent) could potentially give rise to an additional, updated medical examination, particularly if the applicant was seeking to work in the food or health services industries. Further, if any physical or mental conditions were identified in the original or second work permit application, including minor ailments, the work permit file would likely contain more extensive

69 Milay v. Athwal (No. 3) November 19, 2004 (BCHRT).

70 Ibid. para. 11.

71 Citizenship and Immigration Canada, "Medical Examination Requirements, Temporary Foreign Workers” online: CIC <http://www.cic.gc.ca/english/visit/medexams.html>. 
medical records documenting the nature and degree of the condition for immigration authorities.

By requiring the complainant to disclose her employment-related immigration records without determining what types of documents this entailed, the Tribunal in Milay not only jeopardized the Claimant's privacy interests over her medical history, but also supplied the Respondent with materials that, due to their very purpose and nature, are a catalogue of any potential physiological or psychological "problems" with the Claimant. The employment-immigration records were created for a very specific objective, that being to assess the applicant's personal, academic and vocational ability to contribute economically and socially to Canadian society and to estimate the potential costs of the individual's social and health care needs. ${ }^{72}$ For decades, disability rights advocates have argued that the decisions of immigration medical officers are laced with demeaning and paternalistic assumptions about immigrants with disabilities. ${ }^{73}$ Consequently, even though the Tribunal attempted to restrict access by ordering only partial disclosure, this ruling still risked perpetuating serious prejudice. Had the Tribunal looked behind the label of immigration records, the Tribunal would have seen that this label camouflaged substantial amounts of highly personal information, including a potential litany of medical records.

In conclusion, we see that in Milay the Tribunal was not attuned to the underlying confidentiality issues in the disclosure application. This left the Claimant potentially vulnerable to an invasive search of her medical history because of the real possibility that significant medical records were embedded within the demanded employment-immigration documents.

\section{Dayus v. Dawson Creek and District Hospital Foundation ${ }^{74}$}

In Dayus v. Dawson Creek and District Hospital Foundation, the Claimant alleged that, over the course of her two years of employment, her supervisor made demeaning comments about her race (native) and disability (physical), treated her unfairly and assigned her work while she was recuperating from surgery. ${ }^{75}$ She also alleged she quit her employment because of the on-going discriminatory treatment.

At the hearing, the Respondents sought disclosure of the Claimant's Canada Pension Plan (CPP) file. The Respondents claimed disclosure of the CPP file was necessary to demonstrate the Claimant's decision to end her employment

72 The medical admissibility provisions in the Immigration and Refugee Protection Act, S.C. 2001, c. 27 at s. $38(1)$ (c) require medical officers to assess and predict whether the immigration applicant may reasonably be expected to cause excessive demands on Canadian health or social services.

73 Judith Mosoff, "Excessive Demand on the Canadian Conscience: Disability, Family and Education" (1999) 26 Man. L. J. 149. See also Rose Voyvodic, "Into the Wasteland: Applying Equality Principles to Medical Inadmissibility In Canadian Immigration Law" (2001) 16 J.L. \& Soc. Pol'y 115 at 121 , and Chantal Tie, "Only Discriminating Visa Officers Need Apply" (1999) 42 Immigration Law Review. (2d).

74 Dayus v. Dawson Creek and District Hospital Foundation and Cleave [2004] B.C.H.R.T.D. No. 169.

75 Dayus v. Dawson Creek and District Hospital Foundation and Cleave [2004] B.C.H.R.T.D. No. 373 at para. 3. 
was motivated by the fact that continued employment negatively impacted her entitlement to receive CPP disability benefits. The Claimant opposed the disclosure request and argued that the documents in her CPP file were privileged.

The Tribunal held the threshold test for the production of documents was whether the CPP file was "potentially or arguably relevant" to a matter in issue in the complaint. ${ }^{76}$ The Tribunal noted that the parties disagreed about the reason for resignation and, therefore, it concluded that the disclosure should be granted because "the documents in Ms. Dayus' CPP file may be relevant to the question of why Ms. Dayus resigned her employment." 77 The Tribunal found that, while the CPP file was confidential, it rejected the Claimant's argument that the file was privileged. ${ }^{78}$ The Claimant was ordered to immediately "produce to the respondents all documents from her CPP file which relate to her entitlement to benefits or the value of her benefits in 2001, 2002 and 2003."79

It appears in Dayus that, yet again, the Respondents' interest in the "potential relevance" of employment-related documents was favoured and the Claimant's privacy interests were overlooked because of the "invisible" nature of the medical information. Notably though, it does seem somewhat incongruous that the Tribunal was unaware that the CPP file would likely contain extensive medical information given that the records being sought by the Respondents related to the Claimant's disability pension.

The CPP disability pension is available to individuals who due to a severe and prolonged disability are unable to work on a regular basis. ${ }^{80}$ In order to be eligible for CPP disability benefits, applicants must provide detailed information about their work history, as well as their medical condition and a comprehensive medical report has to be completed by their physician, confirming the nature, degree and history of the disablement, observations regarding the psycho-social impacts of the disability and work related limitations, and possibly supporting records, such as clinical notes, hospital records and consultant's reports. ${ }^{81}$ The CPP disability program can also require additional personal information from other sources familiar with the applicant's life circumstances, such as social workers. ${ }^{82}$ Based on its study of the CPP disability program, the Standing Committee on Human Resources Development and the Status of Persons with Disabilities reported that physicians observed that, due to the voluminous amount of medical forms, criteria and information required, the CPP disability application process was "a considerable burden." 83

76 Dayus v. Dawson Creek and District Hospital Foundation and Cleave [2004] B.C.H.R.T.D. No. 169 at para 4.

77 Ibid. at para 8.

78 Ibid. at para 12

79 Ibid. at para 24.

80 See Canada Pension Plan (CPP) Disability Benefits, online: HRSDC <http://www.hrsdc.gc.ca/ en/isp/cpp/disaben.shtml>.

81 Ibid.

82 Ibid.

83 Standing Committee on Human Resources Development and the Status of Persons with Disabilities, Listening to Canadians: A First View of the Canada Pension Plan (Disability) Program, June 2003, online: Government of Canada <http://cmte.parl.gc.ca/Content/HOC/ committee/372/huma/reports/rp1032289/humarp05/05-hon-e.htm>. 
Despite expressly acknowledging that the file was confidential, the Tribunal's inquiry into arguable relevance was completely devoid of any privacy considerations or an assessment of what information may be included in the CPP files and what prejudice may flow from that disclosure. Moreover, the Tribunal did not explain why it extended the temporal scope of the order for disclosure of the CPP files for one year beyond the events giving rise to the complaint.

By ordering "all documents" that related to the Claimant's "entitlement" to CPP benefits, the Tribunal in Dayus opened the door to copious amounts of medical information and personal documentation, potentially summarizing the entire span of the Claimant's working life, to be turned over to the Respondents. Once again, it appears the Claimant's privacy interests were subordinated, while the "potential relevance" of employment-related documents was privileged, because of the buried nature of the medical information.

\section{Louis v. Tostenson Pharmacy Ltd. ${ }^{84}$}

Amber Louis was employed by the Respondent pharmacy as a pharmacy technician from September 15 to 24, 2003. Ms. Louis alleged she was dismissed because the Respondents learned that she was pregnant and that she intended to terminate her pregnancy. The Respondents denied the allegations and asserted that the Claimant was dismissed within her probationary period because of her inexperience and poor work performance.

The Respondents launched a disclosure motion seeking production of the Claimant's complete medical records from July 2003 to the time of the hearing. The Respondents alleged that since the Claimant had already disclosed some medical and imaging records regarding her pregnancy, they were entitled to the "entirety" of her clinical files. ${ }^{85}$ The Respondents further argued the Claimant's health records were relevant to the issue of credibility.

The Claimant opposed disclosure of her health records arguing that her medical condition was not relevant and that the extensive period of time for which the Respondents sought disclosure preceded and postdated the events set out in her complaint. The Claimant argued that she did not put her medical records in issue by virtue of the earlier disclosure because the sole purpose of tendering the original medical information was to confirm the fact that she was pregnant at the time in question. The Claimant further opposed the medical disclosure on the basis that her credibility was a collateral issue.

In addition to the medical records, the Respondents sought disclosure of the Claimant's "personal" academic records from her college pharmacy technician program, including marks, transcripts and teacher review documentation. ${ }^{86}$ The Respondents argued that the "whole" of the Claimant's educational file was relevant because the Claimant had voluntarily disclosed one course outline and therefore raised the matter of her education. ${ }^{87}$ The Tribunal noted that with re-

84 Louis v. Tostenson Pharmacy et al., (2004), C.H.R.R. Doc. 04-411, 2004 BCHRT 264.

85 Ibid. at para 9.

86 Ibid. at para 5.

87 Ibid. at para 10. The Tribunal described this disclosure request as follows: "The respondents argue that Ms. Louis has disclosed an outline of one of the courses she took at Sprott-Shaw. 
spect to the education records the Respondents were seeking "any documents relating to the basis on which the respondents allege they terminated Ms. Louis... as well as any documentation relevant to Ms. Louis' credibility." 88

The Claimant objected to disclosure of her educational records because there were no allegations in relation to her college studies, from which she had graduated a year prior to working for the Respondents. The Claimant explained that she had previously produced a copy of a course outline only to confirm that she took that course. The Claimant argued that the "respondents have not established a factual foundation for the precise matter in issue that requires an assessment of credibility based on the documents sought, and further that credibility is a collateral issue." 89

The Tribunal's analysis with respect to the medical records upheld the Claimant's arguments. The Tribunal held the standard for disclosure is that "[a] party seeking disclosure of documents must show that the documents sought may be relevant to the proceedings." 90 The Tribunal found that the Claimant's clinical records did not relate to any issue in the case other than establishing she was pregnant at the pertinent time. With respect to the Respondents' argument that the medical documents were relevant to credibility, the Tribunal held that the Respondents did not provide any information to support this assertion. The Tribunal pointed out that pursuant to "well established evidentiary principles, extrinsic evidence tendered for the sole purpose of impeaching the credibility of a party is generally inadmissible under the collateral fact rule." 91 The Tribunal concluded that "documents that relate only to a party's credibility and are not otherwise relevant to an issue in dispute will not be considered to meet the standard of arguable relevance" and therefore declined the medical disclosure request. ${ }^{92}$

However, in an interesting turn of events, the Tribunal granted the disclosure with respect to the education records. The Tribunal held that, if the Claimant's academic file was sought solely on the basis that the materials were relevant to credibility, the Tribunal would have refused to order disclosure as was the case with the medical records. But, since the educational documents were sought to establish the Respondents' allegations for dismissal, the Tribunal concluded the materials were relevant and therefore an order for disclosure was appropriate. The Tribunal ordered the Claimant to disclose any documents from her "...College which relate to any of the bases on which the respondents allege that they terminated her employment." ${ }^{33}$

Although the Tribunal's refusal to grant medical disclosure would seem to be a successful outcome from the perspective of privacy rights, the Tribunal's reasoning with respect to the educational files does little to foster confidence that human rights tribunals appreciate their obligation to carefully scrutinize

They argue that Ms. Louis herself has determined that the course and her performance in it are relevant, and that the whole of the Sprott-Shaw file should be disclosed.” 
disclosure demands for confidential information and to protect against "fishing expeditions." This ruling leaves the reader with several nagging questions. What aspect of the education file did the Tribunal find to be arguably relevant to "any of the bases on which the respondents allege that they terminated" the Claimant? Given the Tribunal recognized the Claimant's academic information was "personal," why were these materials not evaluated under the rubric of confidentiality? What would the Tribunal have uncovered had it considered the relevancy of the specific contents of the college file?

It is clear from the language of the decision that the Tribunal unquestioningly accepted the Respondents' neutral label of "educational documents" and therefore did not require the Respondents to particularize the documentation and its foundation for seeking those materials. The Tribunal acceded to the Respondents' bald claim that documents, from an educational institution which the Claimant attended over a year before she commenced employment, were arguably relevant to one of the bases of their defence. As a result of acquiescing to the Respondents' neutral label for the documents, the Tribunal did not consider the degree to which the documents were personal and private and, therefore, did not undertake any examination of confidentiality concerns.

If the Tribunal had, at minimum, turned its mind to the contents of a typical post-secondary academic file, the Tribunal would have realized that student records include application forms (often accompanied by personal financial information), transcripts from previous educational institutions, results from standardized admissions testing, letters of reference and/or personal statements, grades transcripts and instructor review reports. If the Tribunal had considered the contents of the specific academic file in dispute, namely a pharmacy technician program, the Tribunal would have realized that given this course of study involved in a health service industry, student records would most likely also include police check, immunization history, chest $\mathrm{x}$-ray or tuberculosis test and depending on the institution's admissions requirements, potentially wide-ranging health records, such as a health certification or medical report. ${ }^{94}$

The Tribunal in Louis was cognizant of the fact that the Claimant's academic history was a "personal" matter; however, the Tribunal did not appear sensitive to the serious invasion of privacy that could flow from disclosing such personal materials. One possible explanation for this disconnect was that the Tribunal was unaware of the private and sensitive nature of the information concealed under the seemingly innocuous title of "education" documents. If the Tribunal

94 For example, one Ontario educational institution offering pharmacy technician program requires a "comprehensive physician health review," in addition to the "required immunization (Hepatitis B and Flu shots), completion of a Mantoux Test or a chest x-ray (TB exposure), and Police record check." This Ontario college explains the mandatory health reporting admission criteria on the basis that "Ontario legislation specifies certain surveillance requirements for those entering a Health Studies program. In order to comply with the Public Hospitals Act, ministry guidelines and to meet placement setting requirements, an Immunization Review Form specific to each program must be submitted prior to clinical placement. This process is necessary to ensure that those working within health care facilities are free from or are protected against communicable and infectious diseases." See online: Centennial College <http://www. centennialcollege.ca/future/schs_ref_health.jsp>. 
had looked behind the label of educational documents and drilled down into what the contested disclosure might actually entail, the Tribunal would have discovered a myriad of confidential materials having no bearing on the allegations of sex/pregnancy discrimination in employment. In the end, it appears that the Tribunal in Louis did not appreciate that, because of the significant power of the medical profession to validate access and eligibility of a whole host of privileges, including admission into certain fields of study, even academic files can contain confidential medical records. ${ }^{95}$

In Louis, the Tribunal initially properly protected the Claimant's privacy over her medical records by rejecting the Respondents' sweeping and intrusive disclosure demands. However, the Tribunal then proceeded to disclose personal educational materials potentially consisting of confidential medical documentation on the basis that the information was arguably relevant to some vague "bases" of the Respondents' defence. As seen in the previous cases, this confounding outcome was likely due to the lack of transparency regarding the contents of the education file, as well as the Tribunal's superficial analysis of arguable relevance with respect to the educational materials.

Clearly, the first part of the Tribunal's ruling in Louis was encouraging because the Tribunal rejected the Respondents' demands for wholesale disclosure of medical records on the ground of irrelevancy and hence found it unnecessary to proceed with the remainder of the relevance-confidentiality test. However, the Tribunal's treatment of the educational documents was discouraging and paradoxical in result, given the real possibility that personal and medical information about the Claimant was likely intermingled with her educational records. In conclusion, because of the juxtaposition of the disclosure demands for medical and academic information and the differing rulings in relation to these materials, the Louis case is a startling and stark example of the capacity of "official" labels to mask highly personal and confidential information and thereby undercut the privacy rights of human rights claimants.

\section{B. Neutral Labels Mask Medical Information}

As demonstrated by the above three cases, few tribunals can resist the allure of "arguable relevance" when the disclosure sought is classified as employmentrelated. Even fewer tribunals are prepared to probe beyond the respondent's bare assertions of likely or potential relevance. And seldom did tribunals look behind the title of the documents to assess whether, despite the respondent's use of neutral labels, the materials contained confidential information.

The "invisible records" phenomenon was not limited to British Columbia - the survey uncovered similar situations in two other major human rights jurisdictions. Disclosure rulings from the Federal and Ontario jurisdictions reveal occasions where those tribunals also did not grasp the medicalized nature of a variety of materials and, consequently, failed to undertake a confidentiality assessment with respect to the particular documents. Other examples of "invisible" medical records included various cases in which respondents sought access to pension, unemployment, income tax and social assistance files, all of which rou-

95 See discussion in Section 7 of this article. 
tinely contain highly personal information, as well as medical documentation. ${ }^{96}$ When an issue of confidentiality was discerned, tribunals routinely gave little or only hurried consideration to how the relevance-confidentiality principles applied to the general materials without regard to the specific content of the disclosure and, ultimately, discounted the claimant's privacy rights.

Examples of more conspicuous medical information that surprisingly also remained "hidden" and, therefore, unidentified as medical disclosure, are instances where respondents sought access to worker's compensation files and insurance records. ${ }^{97}$ The types of medical information typically found in such files include items like: physician's letters or reports to certify disability, applications with detailed medical and personal histories submitted in order to qualify for benefits or services, receipts of medication prescriptions for funding or reimbursement, receipts of medical aids/equipment for funding or reimbursement, social worker reports, home audits and family interviews documenting care needs, etc.

Thus, a staggering amount of personal information can be accessed when a tribunal turns over government records, like workers' compensation, pension or social assistance files, as virtually every aspect of a claimant's life is catalogued in these materials, including personal details about the claimant's family situation. For example, the application process in order to obtain disability-related social assistance in Ontario involves "a broad range of personal information related to personal and family composition, assets and income" much "of which is far from straightforward." ${ }^{88}$ Consequently, we see that disclosure of such materials may extend beyond the claimant and include release of information about a spouse's income or the family background, all of which is often documented in pension, social services or workers' compensation records.

96 In Tubbs v. Universal Workers Union (No. 1) 2005 HRTO 16, the Respondent sought disclosure of the Claimant's personal income tax records. In Green v. Public Service Commission et al. (July 3, 2003) 2003 CHRT 25 (CHRT), the Respondent also sought disclosure of the Claimant's income tax records. In Fariba Mahmoodiv. Donald Dutton and University of British Columbia (May 8, 1998) (BCHRT), the Respondent sought production of the Claimant's Employment Insurance records. In Dean Travers v. British Columbia Building Corporation, et. al. (December 16, 2004) (BCHRT), the Respondents sought information regarding the Claimant's CPP disability benefits and Employment Insurance benefits. In Alexander v. Province of British Columbia (Ministry of Health Services) (July 28, 2005) (BCHRT), the Respondent sought access to the Claimant's the Ministry of Employment and Income Assistance file.

97 In Jeffrey v. Dofasco Inc. (No. 1) (1999), C.H.R.R. Doc. 00-178 (Ont. Bd.Inq.), the Respondent sought disclosure to the Claimant's CPP, income tax and workers' compensation records. In Hutchinson v. Province of British Columbia and Vancouver Regional Health Board (June 26, 2001) (BCHRT), the Respondent sought the Claimant's personal injury insurance documents. In Day v. Department of National Defence and Hortie (December 6, 2002)(CHRT), the Respondent sought the Claimant's workers' compensation records. In Vetro v. Klassen and Pacific Transit Cooperative No. 2 (June 24, 2005)(BCHRT), the Respondent sought disclosure of the Claimant's personal injury insurance documents. In Ghinis v. Crown Packaging Ltd. (September 11, 2002) (BHCRT), the Respondent sought disclosure of the Claimant's disability insurance records.

98 For e.g. In Denial by Design, Fraser et al indicated that, in order to obtain financial and employment supports associated with the Ontario Disability Support Program, social assistance applicants must complete an "exceedingly complex application process of lengthy medical reports”, see John Fraser, Cynthia Wilkey \& JoAnne Frenschkowksi, Denial by Design: The Ontario Disability Support Program, (Toronto: Income Security Advocacy Centre, 2003) at 8. 
Few tribunals were attentive to the existence of "buried" medical records and consequently, many tribunals either undertook deficient relevance-confidentiality analyses or entirely neglected to apply this methodology. Tribunals appeared to approach the disclosure analysis as if medical records are discrete, free-standing, indelibly marked files and, as a result, frequently accorded short shrift to the relevance-confidentiality analyses because the requested materials did not bear the label of medical records.

The caselaw survey revealed that the use of neutral categories, along with legal labels, masks the medical character of certain records and deflects attention from the confidential concerns. The various rationales presented by respondents to justify their disclosure demands was cloaked in legal jargon, e.g., relevant to mitigation, credibility, damages, etc, and appeared to reconfigure the demanded materials from personal documents into legal records. Such a reconfiguration appeared to accord a legal veneer to the information, which, in turn, created a semblance of relevance. This process both erases the disclosure request of its medical content and triggers ajar the "arguable relevance" door to allow disclosure.

These cases demonstrate that the relevance-confidentiality principles promulgated by human rights tribunals to protect privacy and guard against undue disclosure are rarely employed by tribunals when the disclosure applications involve "invisible" medical information. These cases further suggest that the use of legal categories sanitize disclosure demands of any medical implications and frustrate the objectives of the relevance-confidentiality methodology. In conclusion, the concern arising from the section 5 data analysis, which revealed that there is no heightened degree of protection for medical records as compared to non-medical information, is compounded by the "invisible records" phenomenon, wherein the privacy interests in medical information is ignored because the records wear the mask of neutral labels and legal categories.

\section{DISABILITY IMPLICATIONS}

It appears that in addition to the "invisible records" phenomenon, there are other powerful dynamics at force which risk the disclosure of confidential medical information. One such dynamic is the overarching expectation of medical certification imposed upon human rights claimants, the majority of whom are people with disabilities. The daily affairs of persons with disabilities are inextricably intertwined with their medical status and, as such, their private medical information is subsumed into an array of different social and economic arenas.

The dominant ideology of separate spheres of public and private is not the reality for the disability community. The reality for claimants with disabilities is that a significant amount of their private medical information is adjunct to other records (economic, educational, employment, etc.), which based solely on document titles or categories do not implicate the material as confidential medical information. In failing to appreciate the social authority of medicine over the disability community and how the medical profession, its language and documents, saturate all aspects of the lives of persons with disabilities, tribunals are unaware of the need to carefully examine disclosure demands for medical 


\section{information. ${ }^{99}$}

Part of the difficulty may be that human rights tribunals are unconscious of how people's medical status routinely interfaces with other aspects of their social interactions and how pervasive the "medical certification" expectation is in our daily lives. Critical disability theorists argue this naiveté is especially problematic given the distinct disability implications posed by the "medical certification" process and the magnitude of the power exerted by those responsible for issuing, as well as approving, of the certification. People with disabilities are frequently subjected to the requirement of medical verification simply to access mainstream privileges, such as transportation, education, social and medical services. ${ }^{100}$

As many disability theorists have explained, the separation between public and private is particularly complicated for the disability community because, in order to qualify for accommodation and assistance, persons with disabilities must supply detailed information about their disability and personal lives. ${ }^{101}$ Frazee et al. decry how, in Ontario, a disability benefits applicant "must make extensive disclosure and provide access to financial, health, and other personal information and records of herself as well as her dependents." 102 Also spotlighting the degree to which benefit entitlement is dependent upon medical verification and the problematic role of the medical profession as "gatekeepers" in the lives of persons with disabilities, the Canadian Council of Disabilities points out that:

In order to gain entitlement to different benefits Canadians with disabilities must be certified as eligible by a medical professional. In fact, many individuals with disabilities visit their medical doctor more for certification of the Disability Tax Credit, CPP Disability Pension, Disabled Parking Certificates, the opportunity to travel on Air Canada with an attendant for half price, etc. than they ever do for any medical reason. ${ }^{103}$

99 Susan Wendell, The Rejected Body: Feminist Philosophical Reflections on Disability (New York: Routledge, 1996) particularly "The Cognitive and Social Authority of Medicine" at 117-138. Wendell explains the phrase "cognitive authority" is used to describe the capacity of a person to have their view of the world (or their own body) accepted as reality. She argues that because the medical profession wields such enormous cognitive and social authority with respect to diagnosis and treatment of illness and disabilities, medical professionals have the final word on what conditions will be treated as genuine.

100 With respect to the need for medical certification in the support services, see Kari Krogh and Jon Johnson, "A Life without Living: Challenging Medical and Economic Reductionism in Home Support Policy for People with Disabilities" in Richard Devlin and Dianne Pothier eds., Critical Disability Theory: Essays in Philosophy, Politics, Policy and Law (Vancouver: University of British Columbia Press, 2006) at 160.

101 With respect to the need for medical certification in the education setting, see Terri Hibbs and Dianne Pothier, "Post-Secondary Education and Disabled Students: Mining a Level Playing Field or Playing in a Minefield" in Devlin \& Pothier, ibid at 195.

102 C. Frazee, J. Gilmour \& R. Mykitiuk, "Now you See Her, Now You Don't: How Law Shapes Disabled Women's Experience of Exposure, Surveillance, and Assessment in the Clinical Encounter," in Devlin and Pothier, ibid. at 239.

103 Council of Canadians with Disabilities. (2002). Consumers with Disabilities Speak Out On 
Clearly, concerns regarding undue disclosure of private medical records are exacerbated for persons with disabilities, who because of their frequent contact with the medical system, are disproportionately more often the subject of confidential documentation and, therefore, at greater risk of having their personal information revealed. These concerns are also heightened for women with disabilities whose lives are subject to intense medical scrutiny and more heavily documented than their non-disabled peers. ${ }^{104}$ Consequently, safeguarding privacy of medical records in human rights litigation should be an important issue for claimants with disabilities and, in particular, women with disabilities.

The fact that only one of the three cases explored above indentified disability as the ground for discrimination highlights the exposure of all human rights claimants to having their confidential medical information opened for respondent scrutiny. These cases reveal that, notwithstanding what ground is cited, all human rights claimants are vulnerable to medical disclosure, albeit the information targeted by the respondents may, at first glance, not be regarded as health related. However, this is not to suggest that gendered and disability implications uncovered in section 5 are inconsequential. In fact, given that two of the three cases involved gender-related grounds and the third was disability-based, the "gendered-disability" implications of disclosure demands come into sharper focus. We see that the quandary of "invisible" medical records is compounded for both women and persons with disabilities because of the intricate web of medical information knitted throughout all facets of their lives.

\section{CONCLUSION}

Until the early 1990s, it was a well-settled principle in human rights law that parties were only required to disclose information and materials that they would rely on at the hearing. By the mid-1990s, this less obligatory, strategic approach to disclosure was set aside for a broader and mandatory approach to disclosure. With the goal of fostering fairness and facilitating the efficiency of the hearing process, modern administrative law principles engendered a compulsory obligation of full, mutual and on-going disclosure. The duty of disclosure in human rights law now requires parties to share all arguably relevant information and documents in their possession or control relating to any matter in the complaint, notwithstanding whether the potential disclosure is favourable or adverse to their case. Consequently, the past decade has seen massive growth in disclosure human rights litigation.

This article suggests that claimants' privacy rights are too often the casualty of "arguable relevance" in human rights disclosure litigation. The data in section 5 revealed the troubling fact that there appears to be no greater degree of protection for medical records than non-medical information. The study found that, in contrast to the $76 \%$ of general disclosure requests which were granted in full

Health Issues (Submission to the Romanow Commission on the Future of Health Care in Canada). Winnipeg, Manitoba, Canada, online: Council of Canadians with Disabilities <http:// www.ccdonline.ca/publications/Health\%20Issues/healthissues.htm\#Home\%20Support\%20 and\%20People\%20with\%20Disabilities>.

104 Frazee et al., supra note 102. 
or in part, $81 \%$ of medical disclosure requests were granted in full or in part. The jurisprudential survey suggests that tribunals frequently neglected to apply the relevance-confidentiality framework, while others did so in a lax or perfunctory manner. Unfortunately, because few tribunals undertook a full arguable relevance analysis, the study found numerous examples of grave intrusions on the privacy rights of claimants. Indeed, this article concludes that the confidentiality concerns of human rights claimants (in particular, women and people with disabilities) are often compromised or outright ignored.

Despite the rhetoric advancing a stringent test for disclosure of medical information, we see that in human rights litigation the test of "arguable relevance" fulfills the old adage "seek and you shall find." The caselaw survey discovered that claimants' medical records were rendered invisible by being buried in documents bearing neutral labels. Tribunals routinely failed to look behind the document titles and legal categories put forth by the respondents which concealed the medical information. We saw that the right of full answer and defence was given primacy when personal or medical records were amalgamated with employment documents or government files. An important lesson to be realized from these cases is that human rights tribunals should not simply yield to the categories and labels attached by parties to the disclosure documents and need to look behind the labels for an understanding of what information the materials actually contain in order to ensure that privacy and equality interests are respected.

This article posits that disclosure adjudication cannot be treated as a binary exercise of "all or nothing," "confidential or not confidential," "relevant or irrelevant" and "medical or non-medical." The Supreme Court of Canada has recognized that medical disclosure is an especially sensitive topic which requires heightened attention to the privacy, equality and justice dimensions underlying the inquiry. This article submits that these dynamics of privacy, equality and justice are particularly complex for people with disabilities. Tribunals need to be cognizant that equality issues implicated in disability and gender disclosure litigation mandate that the standard of "arguable relevance" be a meaningful test concomitant with the fundamental nature of human rights.

Human rights tribunals now have unprecedented power to both grant, as well as to deny, disclosure. Whatever outcome a tribunal selects to dispose of disclosure demands, it must respect due process, equality, privacy and uphold the administration of justice. The caselaw discussed in this article suggests that disability, gender and human rights advocates should be concerned about the large number of disclosure applications that are granted and the magnitude of the medical disclosure that is being directly and indirectly released. Ostensibly the relevance-confidentiality methodology is formulated to promote fairness by respecting the interests of all parties to the proceeding. However, when tribunals spoke of fairness, much of the analysis was couched in the vocabulary of "full answer and defence" and hazy generalizations of "arguable relevance." This approach ignored that when considering relevance-confidentiality principles, fairness inheres to the claimant, the respondent and the administration of justice and, therefore, must be evaluated from all perspectives. A fair disclosure process is a right enjoyed by all parties to the litigation, including the public who have an interest in a just and respectful human rights system. 